\title{
Bacteriophages, a New Therapeutic Solution for Inhibiting Multidrug-Resistant Bacteria Causing Wound Infection: Lesson from Animal Models and Clinical Trials
}

This article was published in the following Dove Press journal:

Drug Design, Development and Therapy

\author{
Majid Taati Moghadam ${ }^{1,2}$ \\ Amin Khoshbayan (iD) ${ }^{2}$ \\ Zahra Chegini ${ }^{3}$ \\ Iman Farahani (iD ${ }^{4}$ \\ Aref Shariati $\left.{ }^{5}\right)^{5}$
}

'Jiroft University of Medical Sciences, Jiroft, Iran; ${ }^{2}$ Department of Microbiology, School of Medicine, Iran University of Medical Sciences, Tehran, Iran; ${ }^{3}$ Student Research Committee, Iran University of Medical Sciences, Tehran, Iran;

${ }^{4}$ Department of Microbiology and Immunology, School of Medicine, Arak University of Medical Sciences, Arak, Iran; ${ }^{5}$ Department of Microbiology, School of Medicine, Shahid Beheshti University of Medical Sciences, Tehran, Iran
Correspondence: Aref Shariati Email arefshariatiOIII@sbmu.ac.ir

\begin{abstract}
Wound infection kills a large number of patients worldwide each year. Staphylococcus aureus, Klebsiella pneumoniae, Acinetobacter baumannii, and Pseudomonas aeruginosa are the most important colonizing pathogens of wounds that, with various virulence factors and impaired immune system, causes extensive tissue damage and nonhealing wounds. Furthermore, the septicemia caused by these pathogens increases the mortality rate due to wound infections. Because of the prevalence of antibiotic resistance in recent years, the use of antibiotics to inhibit these pathogens has been restricted, and the topical application of antibiotics in wound infections increases antibiotic resistance. Therefore, finding a new therapeutic strategy against wound infections is so essential since these infections have a destructive effect on the patient's mental health and high medical costs. In this review, we discussed the use of phages for the prevention of multidrug-resistant (MDR) bacteria, causing wound infection and their role in wound healing in animal models and clinical trials. The results showed that phages have a high ability to inhibit different wound infections caused by MDR bacteria, heal the wound faster, have lower side effects and toxicity, destroy bacterial biofilm, and they are useful in controlling immune responses. Many studies have used animal models to evaluate the function of phages, and this study appears to have a positive impact on the use of phages in clinical practice and the development of a new therapeutic approach to control wound infections, although there are still many limitations.
\end{abstract}

Keywords: bacteriophages, multidrug-resistant bacteria, new therapeutic solution, wound infection

\section{Introduction}

The skin is the largest external organ in the body that is in contact with the external environment. ${ }^{1}$ Skin plays an important role in protecting internal organs, ligaments, bones, and underlying tissues from various physical and chemical agents. ${ }^{2}$ Wounds and skin damage can be induced by heat, colds, rays and chemical burns, cuts, various surgeries, or an underlying disease such as diabetes. ${ }^{3}$ In general, wounds are divided into acute and chronic categories. Types of acute ulcers include surgical wounds, insect bites, burns, cuts, and abrasions that expected to heal within a predictable time frame; however, given the severity of the injury, treatment options can speed up the healing process. ${ }^{4}$ But in most cases, severe skin damage 
from burns or gunshot wounds requires surgery debridement and antimicrobial therapy. In contrast, chronic wounds are mostly caused by internal mechanisms associated with an underlying predisposing disease such as diabetes or immune deficiency. The examples of these types of wounds are leg and arterial ulcers, nonhealing surgical wounds, and diabetic foot ulcers. ${ }^{4,5}$ Other risk factors, including foreign bodies, old age, chronic diseases such as diabetes, overweight, immune-deficient diseases, and infection with microorganisms, may also exacerbate chronic wounds. ${ }^{1,6,7}$

Wound infection, frequent types of nosocomial infections, affects many people around the world each year and has a high mortality rate. ${ }^{3,8}$ In healthy and immunocompetent individuals, the immune system naturally plays a protective role against infectious agents, but in the event of an immunodeficiency, various microbial pathogens will damage the underlying tissues, spread throughout the body, resulting in disruption of different organs and even death. ${ }^{9}$ Wound infection is often caused by the entry of bacterial pathogens through the other parts of the body or the environment into the skin gaps, and depending on the type of pathogen, adjacent tissues may also be involved. Pseudomonas aeruginosa, Staphylococcus aureus, Klebsiella pneumoniae and Acinetobacter baumannii are common bacteria that cause wound infection., 2,3,10 These pathogens can cause damage and infections by utilizing various virulence factors. ${ }^{11-13}$ Wounds, especially burn wounds, in the first week are colonized by grampositive pathogens such as $S$. aureus, and from the beginning of the second week, the gram-negative pathogens enter the wound. ${ }^{11}$ As the proliferation of microorganisms increases, the invasion of deeper tissues begins, and when pathogens enter the lymphatic and blood vessels, sepsis develops, which significantly worsens the prognosis. Sepsis is the most severe clinical form of infection in patients with infected wounds, especially in the burn unit patients who require urgent treatment, and $P$. aeruginosa and $A$. baumannii are particularly dangerous because of lipopolysaccharides in their cell walls which is highly toxic and causes a severe immune response. ${ }^{12}$

Different antibiotics (carbapenems, aminoglycoside, colistin and the b-lactam/b-lactamase) have been used to inhibit bacterial wound infections, but today their use has been restricted due to the toxicity and prevalence of multidrug-resistant (MDR), extensively drug-resistant (XDR), and pandrug-resistant (PDR) pathogens which seriously threaten human health. Recently, the United Nations claimed this as a global challenge and it is predicted that 10 million people will die because of these pathogens by $2050 .{ }^{14,15}$ Furthermore, in wound infections, intravenous antibiotic therapy may not be able to inhibit MDR bacteria because of the presence of various factors such as hyperperfusion, fibrosis, granulation tissue, and necrosis. These factors do not allow antibiotics to penetrate the damaged tissues. Of note, topical use of antibiotics in wound infections may also be unsatisfactory due to dilution by effusion fluids, or inactivation by enzymes, or other inflammatory mediators. ${ }^{16,17}$ Therefore, the use of novel solutions such as nanoparticles, natural products with antimicrobial properties such as honey and Aloe vera, probiotics, phototherapy and bacteriophages has attracted the attention of researchers. ${ }^{10,18-20}$

Bacteriophages are viruses that specifically invade and kill bacteria using different mechanisms. These microorganisms do not have a receptor for eukaryotic cells, so they can be used to treat various infections and they have received greater attention as antibiotic resistance has expanded. ${ }^{21}$ Noteworthy, bacteriophages are abundant in the ecological environment such as water, oil and sewage, the mechanisms of antibiotic resistance do not impair their function and due to their proliferation in the area of infection, unlike antibiotics, they do not require multiple doses. ${ }^{22}$ Recent studies have reported that bacteriophages properties such as selfproliferation, high immunity with low side effects for eukaryotic cells, stability in different environmental conditions, and efficient activity against MDR pathogens, can be considered as a potential replacement for antibiotics. ${ }^{23,24}$

Therefore, due to the enormous healthcare expenditures, significant cause of morbidity and mortality and mental injuries caused by nonhealing and chronic wounds to patients, and reducing the use of antibiotics, in this study for the first time, we investigated the performance of different bacteriophages on the most important MDR pathogens of wound infection to identify their advantages and disadvantages, to shed light on their ability to inhibit these pathogens.

\section{Phage Therapy Against MDR, XDR, and PDR Bacteria in vitro and in vivo}

The United States spends billions of dollars annually in health care for controlling drug-resistant infections; these infections add 8 million days to hospitalization. Studies show that more than 25,000 patients annually in European hospitals become resistant to antibiotics due to MDR 
bacterial infection. ${ }^{21}$ The levels of antibiotic resistance vary among bacteria and include MDR, XDR, and PDR. In this respect, MDR organisms are so important because they are resistant to more than one antibiotic. ${ }^{21}$ Researchers define MDR isolates as resistant to three or more antibiotic classes; however, there is no comprehensive agreement on the standard definition of MDR isolates. ${ }^{21}$ Some bacteria that are considered as XDR are resistant to nearly all antimicrobial agents. The PDR bacteria are resistant to all antibiotics used in the experimental treatment. ${ }^{25}$ The antibiotic resistance is present in both Gram-negative and Gram-positive pathogenic bacteria. Therefore, there is a need to find an effective solution to control these challenging bacteria and prevent their spread. ${ }^{26}$ Various studies in recent years have shown that Gram-positive and Gram-negative bacteria can interfere with antibiotic resistance and cause a high mortality rate among infected patients, such as vancomycin-resistant Enterococci (VRE), methicillin-resistant $S$. aureus (MRSA), extended spectrum beta-lactamase (ESBL)-producing $P$. aeruginosa, Enterobacteriaceae, and XDR A. baumannii. Noteworthy, some resistant bacteria such as extensively antibiotic-resistant tuberculosis (XDRTB), MDR Clostridium difficile, and New Delhi Metallo$\beta$-lactamases (NDM) in Enterobacteriaceae worldwide, especially in developing countries have expanded and can cause greater problems over time. ${ }^{27-30}$ Reports have shown that infections with high antibiotic resistance can result in increased hospitalization time, delay in antimicrobial therapy, use of high toxic antibiotics, increase costs, and many other problems for patients. ${ }^{21,31}$ Because of the widespread resistance to antibiotics and the decline in the production of new antimicrobial agents, phage therapy as a novel, safe and attractive strategy for researchers. ${ }^{21}$ Therefore, phage therapy has become more popular after the occurrence of antibiotic resistance, and now many institutes and researchers are looking for new ways to improve phage therapy. Various studies have used phages to inhibit MDR bacteria. For example, in one study, the researchers examined the phage against MDR $S$. aureus when it posed challenges to treatment. The results indicated that bacteriophage $\phi \mathrm{MR} 11$ rapidly and completely lysed MDR $S$. aureus under growing conditions. Also, the phage killed of MRSA caused infection in mice in vivo. ${ }^{32}$ Pallavali et al evaluated bacteriophages (KP DP1, SA DP1, PA DP4, and EC DP3) isolated from wastewater against MDR bacteria, causing septic wound infections, including $K$. pneumoniae, $S$. aureus,
P. aeruginosa, and E. coli. A volume of $100 \mu \mathrm{L}$ of purified phage (109 PFU-1) lysed the MDR bacteria that cause septic wounds (Figure 1). Therefore, these phages can be used either as prophylaxis to prevent wound infection or as a therapeutic in the treatment of MDR bacteria. ${ }^{33}$ In another study, Mapes et al tested the effects of $\phi E 2005$, $\phi$ Paer4, $\phi P A 2$, and $\phi K M V$ phages on MDR and XDR isolates of $P$. aeruginosa. The results showed that all phages were capable of removing MDR isolates and inhibit biofilm formation, but these phages could not eliminate XDR $P$. aeruginosa. ${ }^{34}$ The effect of three lytic phages, alone or in a cocktail (in combination) against XDR and MDR isolates of $P$. aeruginosa, was investigated in vitro, and it was found that $P$. aeruginosa resistant isolates are highly susceptible to at least one phage and also to the cocktail. There was also a significant relationship between different genotypes and susceptibility patterns of these phages. ${ }^{35}$ In 2017 , phage therapy was performed against 96 P. aeruginosa isolates, including 94 MDR (97.9\%), 2 non-MDR (2.1\%), 63 XDR (65.6\%), and 1 PDR (1.1\%) isolates. The use of cocktails revealed that they had a potential therapeutic effect against a wide range of resistant infections caused by MDR, XDR, and PDR isolates. ${ }^{36}$ Nir-paz et al treated a patient with a traumainduced left tibia infection (infected with XDR A. baumannii and MDR K. pneumoniae) by bacteriophages and antibiotics. After applying combined treatment with bacteriophage and antibiotic, tissue healing and eradication of the infection were observed rapidly and no further amputation was required. ${ }^{37}$ Finally, it is noteworthy that phages have been used in recent years to inhibit various models of infections caused by MDR bacteria such as sepsis, osteomyelitis, intestinal tract infection, keratitis, rhinosinusitis or otitis media, pneumonia and abscesses. ${ }^{16}$ Because of the absence of new antibiotics against MDR, XDR, and PDR, bacteriophages are potential new therapies for such infections. Therefore, bacteriophage are promising tools in the treatment of resistant bacteria that can lead to failure in treatment. In the next sections we have discussed the use of phages for the prevention of most important MDR bacteria causing wound infection and their role in wound healing in animal models and clinical trials.

\section{Pseudomonas aeruginosa}

$P$. aeruginosa is one of the most important pathogens in infections caused by burn wounds. This bacterium causes serious damages to the tissues using various virulent 
C

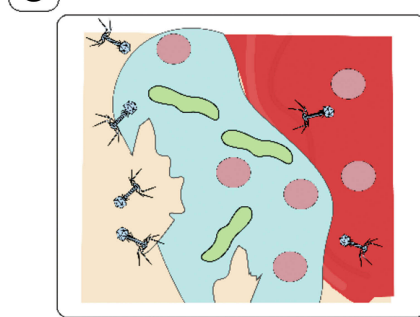

D

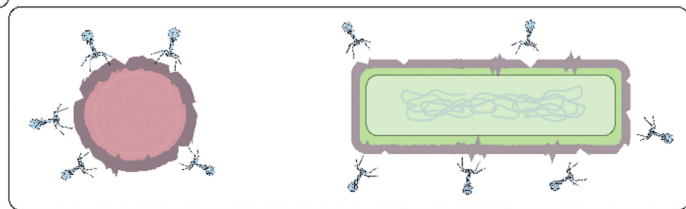

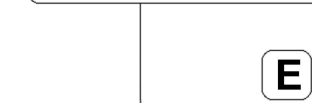

\section{E}

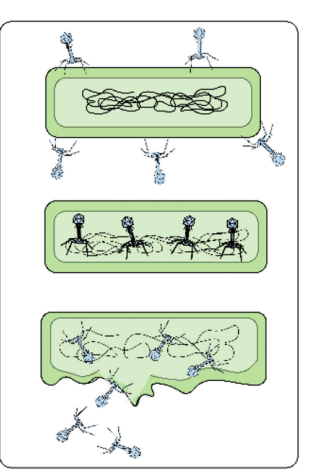

$\mathbf{F}$
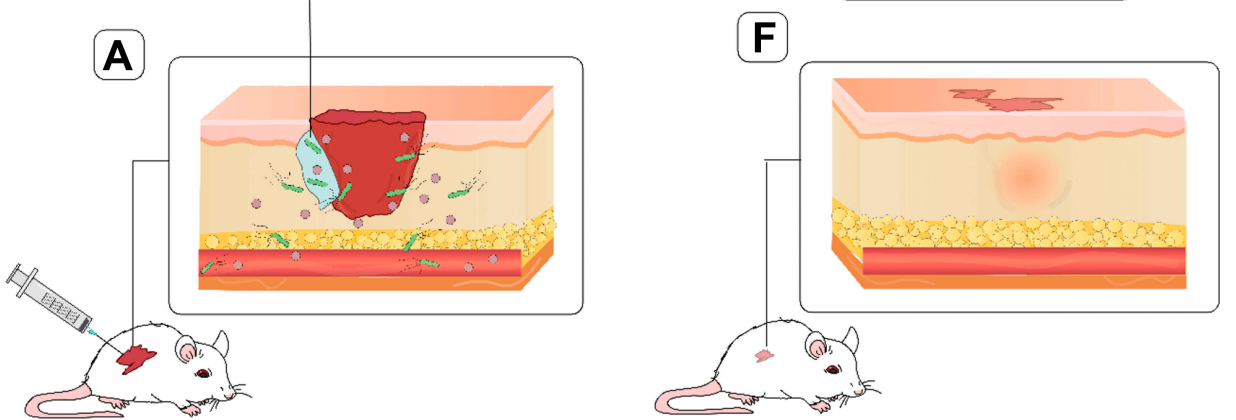

Figure I Different mechanisms of phage therapy for the prevention of wound infections. (A) Bacterial pathogens colonize the wound. (B) Bacteriophages inhibit septicemia caused by bacterial pathogens. (C) Bacterial biofilm created in the wound, one of the main reasons for antibiotic resistance, is destroyed by bacteriophages. (D) Bacteriophages reduce the invasive properties of bacteria by destroying bacterial virulence factors such as capsules. (E) Bacteriophages destroy their hosts and inhibit wound infections. (F) Accelerating the process of wound healing has been reported as one of the consequences of using bacteriophages in different wounds.

factors. Also, it is difficult to treat this bacterium due to its high antibiotic resistance. ${ }^{13,38}$

Phage therapy for $P$. aeruginosa infections has been used for more than 50 years. ${ }^{39,40}$ McVay and his colleagues reported that the use of phages can inhibit $P$. aeruginosa strain PAO1 in burn wound infection. A phage cocktail containing $1 \times 10^{8}$ PFU of Pa1 (ATCC 12,175-B1), Pa2 (ATCC 14203-B1), and Pa11 (ATCC 14205-B1) $\left(3.0 \times 10^{8}\right.$ PFU total) was administered intraperitoneally, intramuscularly and subcutaneously to $P$. aeruginosa infected and uninfected burned ND4 Swiss Webster mice. Their results showed that injection of phages intramuscularly and subcutaneously can reduce the mortality rate by $22 \%$ and $16 \%$ in mice, respectively, whereas intraperitoneal administration of phages reduced the mortality rate by $82 \%$. The pharmacokinetics of phage delivery showed that when phages were administered intraperitoneally, a higher dose of phages was delivered, also, the phages reached to their targets faster, and they were more sustained than the other routes. Furthermore, the administration of the phages alone had no detrimental effect on the traumatized mice, and this increases the chances of using phages in the clinical trial studies. ${ }^{41}$ Bacterial biofilm is another therapeutic barrier to prevent wound infections. Basu and his colleagues reported that the phage cocktail solution is capable of destroying biofilm created by an MDR P. aeruginosa in wounds (Figure 1). In this study, after the subcutaneous pockets were created on the mice, biofilmladen catheter sections were placed on the wounds and daily phage cocktail (10 $\mu \mathrm{L}$ of $10^{7}$ phage forming units/ $\mathrm{mL}$ ) injections for 10 days were used to treat them. The results showed that in the phage treated mice, the number of bacteria decreased significantly compared to the control groups, and a significant rise in the phage counts also were observed, indicating the ability of the phages to destroy the MDR $P$. aeruginosa biofilm created in the wound. ${ }^{42}$ In another study, $1 \times 10^{9} \mathrm{PFU} / \mathrm{mL}$ of vB_EcoS_CEB_EC3a 
and PAO1-D were used to destroy the biofilm of $P$. aeruginosa strain PAO1 and clinical E. coli in wounds. Phages reduced the dual-species biofilms formed on polystyrene, and PAO1-D also reduced the biofilm formed by $P$. aeruginosa in porcine skin explants. Noteworthy, in this study, the phage was used combined with different percentages of chestnut honey, the results showed the synergistic effect of this compound as honey with biofilm damage and increased permeability which can contribute to biofilm destruction. ${ }^{43}$ In another interesting study, Honey, polyvinyl alcohol, chitosan nanofibers which were electrospun and loaded with bacteriophage (PS1), were used to inhibit wound infection caused by MRSA and MDR $P$. aeruginosa. This novel green nanofibrous dressings showed significant antimicrobial activity against these pathogens, enhanced biocompatibility and wound healing activity, and represented a highly competitive wound dressing. ${ }^{44}$ In another study, phage Lysins (PlyPa03 and PlyPa91) were used for the treatment of the CD1 mice model of $P$. aeruginosa skin infection. The results showed that these two phage lysins $(100-\mu \mathrm{g} / \mathrm{mL}$ lysins in $30 \mathrm{mM}$ HEPES buffer) can have an inhibitory effect on this bacterium, even in their stationary phase. MBEC biofilm inoculator 96well plate system also showed that $\mathrm{PlyPa} 03$ and $\mathrm{PlyPa} 91$ at concentrations of 0.375 and $1.5 \mathrm{mg} / \mathrm{mL}$, could, completely, destroy the biofilm of $P$. aeruginosa strain PAO1, respectively. Furthermore, $200-\mu \mathrm{g}$ or $300-\mu \mathrm{g}$ dose of PlyPa03 and $100 \mu \mathrm{g}$ of PlyPa91 reduced the bacterial load in the mice model of skin infection. On the other hand, these phage Lysins are inactivated at low concentrations of human serum, so they are not suitable for systemic administration, and it is preferable to use them topically. Of note, phage Lysins used in this study also had good killing activity against Enterobacter and Klebsiella, and PlyPa91 protected mice in a lung infection model. ${ }^{45}$ Soothill et al used phages to inhibit skin grafts destruction by $P$. aeruginosa strain 3719 in guinea-pigs. They reported that $1.2 \times 10^{7} \mathrm{PFU}$ of bacteriophage BS24 isolated from sewage can prevent failure of skin grafts caused by $P$. aeruginosa in pigs while in the control groups, which received no phages this bacterium fails skin grafts. They also suggested that phages can be used as prophylaxis because existing treatments interfere with graft take and topical antibiotics may increase the incidence of antibiotic resistance. So, phages can be used in patients with burn wounds colonized with $P$. aeruginosa before grafting. ${ }^{46}$ QPan70, a member of the Myoviridae family, is another putative temperate phage used to treat wound infection caused by MDR $P$. aeruginosa. This phage has a very high impact on the biofilm of different MDR $P$. aeruginosa strains and cause destruction and delay in the biofilm formation of this bacterium, which increases its potential for use in chronic infections. Furthermore, all of the burned mice infected with $P$. aeruginosa and treated with phage after 45 minutes all survived, whereas the untreated control group died after 3 to 4 days, also, no toxicity or side effects were reported for this phage. ${ }^{47}$ In another ex vivo study, gauze bandages soaked in phage PA709 suspension $\left(10^{7} \mathrm{PFU} / \mathrm{mL}\right)$ then 4 hours of incubation reduced $4 \log$ MDR $P$. aeruginosa in human skin. Noteworthy, this phage showed a wide range of hosts (infected $30 \%$ of the tested $P$. aeruginosa isolates), did not damage the normal skin microbiota and showed very high stability on the human skin and buffer, which increased their capability for the treatment of skin infections caused by MDR $P$. aeruginosa. ${ }^{48}$

In one randomized phase $1 / 2$ trial study, a cocktail of bacteriophages (PP1131) was used to treat burn wounds infected by $P$. aeruginosa. Results showed that topical use of the phage $\left(1 \times 10^{6} \mathrm{PFU} / \mathrm{mL}\right)$ reduced the number of bacteria in the wound in half of the participants at the end of phage treatment. The reason for the topical use of phages in this study was to minimize the side effects of systematic use of endotoxin residues which can increase the risk of side effects. ${ }^{49}$ In another study, topical bacteriophage was used to treat a patient with $50 \%$ surface area burns infected with $P$. aeruginosa. Three days after phage treatment, bacterial were not isolated and no side effects were observed. Also, extensive grafting was successful, and intravenous use of ceftazidime may contributed to the therapeutic process. ${ }^{50}$

Therefore, as shown in the above studies, different phages can have a destroying effect on the biofilm of $P$. aeruginosa in addition to reducing the number of bacteria in wound infections. Furthermore, the mechanism of resistance to phages is completely different from antibiotics, and this increases the possibility of using phages in clinical practice as suitable alternatives to antibiotics. It should be noted that various studies have used the phages to inhibit MDR P. aeruginosa, which may also be suitable candidates for the inhibition of this bacterium in wound infections. Therefore, in Table 1, we provide a comprehensive list of various studies that have used the phages to inhibit and eliminate MDR bacteria.

\section{Acinetobacter baumannii}

A. baumannii is one of the most important pathogens in burn units worldwide. This pathogen is resistant to various antibiotics, also using high toxicity drugs such as colistin can cause serious harm to the patient. ${ }^{74,75}$ The emergence 
Table I Some Phages That Have Been Used to Inhibit Drug-Resistant Bacteria and Can Be Used as Candidates for the Prevention of Wound Infections in Future Studies

\begin{tabular}{|c|c|c|c|c|c|c|c|}
\hline $\begin{array}{l}\text { First } \\
\text { Author } \\
\text { and Year }\end{array}$ & Country & Subject & Condition & $\begin{array}{l}\text { Type of Phage } \\
\text { for Treatment }\end{array}$ & Species & Outcome & Reference \\
\hline $\begin{array}{l}\text { Chang et al } \\
(2019)\end{array}$ & Australia & $\begin{array}{l}\text { Lung epithelial } \\
\text { and fibroblast } \\
\text { cells }\end{array}$ & - & PEV20 & $\begin{array}{l}\text { P. aeruginosa isolated from Cystic } \\
\text { Fibrosis and Wound Patients }\end{array}$ & $\begin{array}{l}\text { PEV20 and ciprofloxacin together } \\
\text { eradicated biofilm more efficient than the } \\
\text { single treatment and preserved the cells } \\
\text { from P. aeruginosa invasion and enhanced cell } \\
\text { growth }\end{array}$ & 51 \\
\hline $\begin{array}{l}\text { Taha et al } \\
(2018)\end{array}$ & Egypt & - & - & ZCKPI & $\begin{array}{l}\text { MDR } K \text {. pneumoniae isolated } \\
\text { from foot wound of a diabetic } \\
\text { patient }\end{array}$ & $\begin{array}{l}\text { Using the phage at high multiplicity of } \\
\text { infection caused a decrease of bacterial } \\
\text { count and biofilm biomass }(>50 \%)\end{array}$ & 52 \\
\hline $\begin{array}{l}\text { Barros et al } \\
(2019)\end{array}$ & Portugal & - & - & $\begin{array}{l}\text { vB_SauM_LMI2, } \\
\text { vB_EfaS_LM99 } \\
\text { vB_EcoM_B75 }\end{array}$ & $\begin{array}{l}\text { MRSA } \\
\text { VRE } \\
\text { E. coli isolates from } \\
\text { orthopedics implant-associated } \\
\text { infections }\end{array}$ & $\begin{array}{l}\text { Phage reduced bacteria and showed } \\
\text { high efficiency and specificity for } \\
\text { infecting the pathogens }\end{array}$ & 53 \\
\hline $\begin{array}{l}\text { Jansen et al } \\
(2018)\end{array}$ & Germany & - & - & $\begin{array}{l}\text { vB_AbaM-KARL } \\
-1\end{array}$ & MDR A. baumannii & $\begin{array}{l}\text { At } \mathrm{MOI} \text { of } \mathrm{IO}-\mathrm{I} \text { and meropenem } \\
(>128 \mathrm{mg} / \mathrm{I}) \text {, liquid cultures get } \\
\text { apparent and antibacterial activity was } \\
\text { significantly augmented with } \\
\text { meropenem }\end{array}$ & 54 \\
\hline $\begin{array}{l}\text { Capparelli } \\
\text { et al } \\
(2007)\end{array}$ & Italy & Mice & Abscesses & $M^{S a}$ & MRSA & $\begin{array}{l}\text { The phage killed bacteria, prevented } \\
\text { abscess formation and caused } \\
\text { a reduction in the bacterial load }\end{array}$ & 55 \\
\hline $\begin{array}{l}\text { Morris } \\
\text { et al } \\
(2019)\end{array}$ & Australia & Rats & $\begin{array}{l}\text { peri- } \\
\text { prosthetic } \\
\text { joint } \\
\text { infection }\end{array}$ & $\begin{array}{l}\text { StaPh_I, StaPh_3, } \\
\text { StaPh_4, StaPh_II } \\
\text { StaPh_16 }\end{array}$ & S. aureus & $\begin{array}{l}\text { Treatment of infection with both } \\
\text { vancomycin and phage caused } 22.5 \text { fold } \\
\text { reduction of bacterial load, while treatment } \\
\text { of phage or vancomycin alone only caused } 5 \\
\text { or } 6.2 \text { fold of redaction }\end{array}$ & 56 \\
\hline $\begin{array}{l}\text { Lehman } \\
\text { et al } \\
(2019)\end{array}$ & USA & Mice & Pneumonia & AB-SAOI & MRSA and VISA & $\begin{array}{l}\text { The phage showed equal effect as } \\
\text { vancomycin in the reduction of } \\
\text { microbial load of lung S. aureus }\end{array}$ & 57 \\
\hline $\begin{array}{l}\text { Takemura- } \\
\text { Uchiyama } \\
\text { et al (2013) }\end{array}$ & Japan & Mice & Septicemia & $\mathrm{S} 13 \mathrm{O}^{\prime}$ & MRSA & $\begin{array}{l}6 \mathrm{~h} \text { after infection, administration of phage } \\
\text { caused a reduction in the severity of the } \\
\text { infection and rescued the infected mice }\end{array}$ & 58 \\
\hline $\begin{array}{l}\text { Ding } \\
(2018)\end{array}$ & China & Nude Mice & $\begin{array}{l}\text { Dermal } \\
\text { Abscess }\end{array}$ & JD007 & MRSA & $\begin{array}{l}\text { The phage prevented bacteria to from } \\
\text { cutaneous abscesses formation, and } \\
\text { immune responses did not robust }\end{array}$ & 59 \\
\hline $\begin{array}{l}\text { Watanabe } \\
\text { et al } \\
(2007)\end{array}$ & Japan & Mice & Septicemia & KPPIO & P. aeruginosa & $\begin{array}{l}\text { Mortality rate reduced by } 66.7 \% \text { and } \\
\text { viable bacteria in blood was decreased }\end{array}$ & 60 \\
\hline $\begin{array}{l}\text { Fukuda } \\
\text { et al } \\
(2012)\end{array}$ & Japan & Mice & Keratitis & Kppl2 & P. aeruginosa & $\begin{array}{l}\text { By using eye-drops of KPPI2, bacterial } \\
\text { clearance significantly enhanced in the } \\
\text { infected cornea and the outcome of the } \\
\text { treatment improved }\end{array}$ & 61 \\
\hline $\begin{array}{l}\text { Wright } \\
\text { et al } \\
(2009)\end{array}$ & UK & Human & $\begin{array}{l}\text { Chronic } \\
\text { otitis }\end{array}$ & $\begin{array}{l}\text { BC-BP-01 to BC- } \\
\text { BP-06 }\end{array}$ & MDR P. aeruginosa & $\begin{array}{l}\text { Bacteria loads in the phage treated group } \\
\text { were significantly reduced, also, a higher } \\
\text { efficacy and safety in chronic otitis } \\
\text { treatment was observed }\end{array}$ & 62 \\
\hline
\end{tabular}

(Continued) 
Table I (Continued).

\begin{tabular}{|c|c|c|c|c|c|c|c|}
\hline $\begin{array}{l}\text { First } \\
\text { Author } \\
\text { and Year }\end{array}$ & Country & Subject & Condition & $\begin{array}{l}\text { Type of Phage } \\
\text { for Treatment }\end{array}$ & Species & Outcome & Reference \\
\hline $\begin{array}{l}\text { Wang et al } \\
(2005)\end{array}$ & China & Mice & Bacteremia & ØА392 & Imipenemresistant $P$. aeruginosa & $\begin{array}{l}\text { The mortality rate decreased by } 100 \% \\
\text { with the first inoculation, } 60 \mathrm{~min} \text { after } \\
\text { the bacterial challenge }\end{array}$ & 63 \\
\hline $\begin{array}{l}\text { Duplessis } \\
\text { et al } \\
(2017)\end{array}$ & USA & Human & $\begin{array}{l}\text { Bacteremia/ } \\
\text { sepsis }\end{array}$ & $\begin{array}{l}\text { Cocktail } \\
\text { of } 2 \text { phages }\end{array}$ & MDR $P$. aeruginosa & Sterilized the bacteremia & 64 \\
\hline $\begin{array}{l}\text { Hua et al } \\
(2018)\end{array}$ & China & Mice & $\begin{array}{l}\text { Lung } \\
\text { infection }\end{array}$ & $\mathrm{SH}-\mathrm{Ab}$ I55I9 & $\begin{array}{l}\text { Carbapenem-resistant } \\
\text { A. baumannii }\end{array}$ & $\begin{array}{l}\text { Reduced the mice fatality rate in the } \\
\text { treated group }\end{array}$ & 65 \\
\hline $\begin{array}{l}\text { Schooley } \\
\text { et al } \\
(2017)\end{array}$ & USA & Human & $\begin{array}{l}\text { A } 68 \text {-year- } \\
\text { old diabetic } \\
\text { patient } \\
\text { with } \\
\text { necrotizing } \\
\text { pancreatitis }\end{array}$ & $\begin{array}{l}\text { AB-Navyl } \\
\text { AB-Navy4 } \\
\text { AB-Navy7I } \\
\text { AB-Navy97 } \\
\text { AbTP3ழI } \\
\text { AC4 } \\
\text { CIPI2 } \\
\text { C2P2I } \\
\text { C2P24 }\end{array}$ & MDR A. baumannii & $\begin{array}{l}\text { Reversed the patient's downward } \\
\text { clinical trajectory, clearance of the } \\
\text { A. baumannii infection raised, and } \\
\text { a return to the health happened }\end{array}$ & 66 \\
\hline $\begin{array}{l}\text { Wang et al } \\
(2018)\end{array}$ & Taiwan & Mice & Bacteremia & $\phi k m / 8 p$ & XDR A. baumannii & $\begin{array}{l}\text { Phage therapy caused an increase in the } \\
\text { survival rates in animals, reduced } \\
\text { bacteria counts and levels of } \\
\text { inflammatory markers }\end{array}$ & 67 \\
\hline $\begin{array}{l}\text { Wang et al } \\
(2015)\end{array}$ & China & Mice & Pneumonia & $\begin{array}{l}\text { vB_AbaM-IME- } \\
\text { AB2 }\end{array}$ & MDR A. baumannii & $\begin{array}{l}\text { After bacteria challenge, intranasal } \\
\text { phage installation caused survival of } \\
100 \% \text { of animals }\end{array}$ & 68 \\
\hline $\begin{array}{l}\text { Hung et al } \\
(2011)\end{array}$ & Taiwan & Mice & $\begin{array}{l}\text { Liver } \\
\text { Abscesses } \\
\text { and } \\
\text { Bacteremia }\end{array}$ & $\varphi \mathrm{NK5}$ & K. pneumoniae & $\begin{array}{l}\text { Single dose administration of phage at } \\
30 \text { min after bacterial infection was } \\
\text { rescued mice }\end{array}$ & 69 \\
\hline $\begin{array}{l}\text { Cao et al } \\
(2015)\end{array}$ & China & Mice & Pneumonia & 1513 & MDR K. pneumoniae & $\begin{array}{l}\text { After } 2 \mathrm{~h} \text { of bacteria inoculation, a single } \\
\text { intranasal administration was able to save } \\
\text { mice against pneumonia }\end{array}$ & 70 \\
\hline $\begin{array}{l}\text { Chhibber } \\
\text { et al } \\
\text { (2008) }\end{array}$ & India & Mice & $\begin{array}{l}\text { Respiratory } \\
\text { infection }\end{array}$ & SS & K. pneumoniae B5055 & $\begin{array}{l}\text { All of the mice were survived by } \\
\text { immediate administration of phage } \\
\text { after bacteria challenge }\end{array}$ & 71 \\
\hline $\begin{array}{l}\text { Anand et al } \\
(2019)\end{array}$ & India & Mice & Pneumonia & VTCCBPA43 & K. pneumoniae & $\begin{array}{l}\text { Bacteria count in lung decreased } \\
\text { significantly, and the lesion severity was } \\
\text { declined }\end{array}$ & 72 \\
\hline $\begin{array}{l}\text { Corbellino } \\
\text { et al } \\
(2019)\end{array}$ & Italy & Human & $\begin{array}{l}\text { A 57-year- } \\
\text { old patient } \\
\text { with multi- } \\
\text { site } \\
\text { colonization } \\
\text { of bacteria }\end{array}$ & - & MDR K. pneumoniae & $\begin{array}{l}\text { There was no sign of bacteria by the } \\
\text { culture of molecular screening after } 3 \\
\text { weeks of phage therapy }\end{array}$ & 73 \\
\hline
\end{tabular}

Abbreviations: MDR: multidrug resistance, XDR: extensively drug-resistant, PDR: pan drug-resistant, MRSA: methicillin-resistant S. aureus, VISA: vancomycin intermediate S. aureus, VRE: vancomycin-resistant enterococcus. 
of antibiotic resistance has imposed restrictions on the topical use of antibiotics in wounds, therefore finding new solutions to control MDR A. baumannii is crucial because infection to this bacteria can increase the mortality rate of patients with wound infection by several times because of septicemia. $^{76}$ So, using phages due to their lower side effects and their specific mechanism on the bacterium can be considered as a potential treatment to inhibit MDR A. baumannii in burn wounds.

James and his colleagues reported that Cocktail of wild environmental phages (AB-Navy1, AB-Navy2, ABNavy3, and AB-Navy4) can inhibit the wound infection caused by MDR A. baumannii clinical isolates in mice. In vitro results showed that phages have a good ability to kill MDR A. baumannii and after a full-thickness dorsal wound in neutropenic mice and infecting them with MDR strains of $A$. baumannii, phages decrease the bioburden in the wound and infection-associated morbidity; also, they prevent the spread of infection, biofilm formation, and necrosis of the surrounding tissue. Noteworthy, AB-Navy1, in this study, showed a high impact on the capsule production by this bacterium, and the results of the Galleria mellonella model showed that phages which target the A. baumannii capsule, make the bacteria avirulent, and this can have a great impact on the incidence of strains control (Figure 1). On the other hand, they reported that 10 out of the 92 clinical tested isolates were infected with phages. This phenomenon highlights the narrow spectrum of phages and the crucial need for specialization of the therapeutics against MDR infections by developing phages. $^{77}$ In another study, Galleria mellonella and a mouse model were used to assess the bactericidal effect of vB_AbaM_3054 and vB_AbaM_3090 phages on the XDR $A$. baumannii. Two hours after the infection of mice with $6 \times 10^{7} \mathrm{CFU}$ of XDR $A$. baumannii, phages were administrated intraperitoneally alone or in combination for treatment. In the untreated control group, all of the mice were died after one day, while the phage-treated group survived for up to seven days. On the other hand, imipenem (a single bolus injection of $50 \mathrm{mg} / \mathrm{kg}$ ) was not able to extend the survival of the mice. The results suggested that phages were efficient in the treatment of bacteremia caused by XDR $A$. baumannii. ${ }^{78}$ Yin et al used Abp1, lytic phage of the pan-drug resistant $A$. baumannii strain AB1, to treat MDR A. baumannii -induced wound infection in mice. In this study, after full-thickness wounds on mice, $5.0 \times 10^{4}$ MDR $A$. baumannii cells were used to infect wounds then $5.0 \times 10^{8}$ PFU of phage was inoculated by subcutaneous injection or direct pipetting of phages into the wound to inhibit the infection. Furthermore, the same number of phage was administrated intraperitoneally for the treatment of $A$. baumannii -induced bacteremia in mice. The results showed that topical use of Abp1 for the treatment of wound infection by MDR A. baumannii can improve wound healing and reduce infection, and extend the survival of bacteremia-induced mice up to seven days and reduce bacterial load in animal organs. Noteworthy, Abp1 did not show any detectable toxic effects on HeLa or THP-1 cells and was stable under a wide range of temperatures and $\mathrm{pH}$ values that increase the potential use of Abp1 in the burn units. ${ }^{79}$ In another study, phage PD6A3, purified endolysin of this phage (Ply6A3), and phage cocktail (contain 14 different phages) were used to treat mice bloodstream infections caused by clinical MDR A. baumannii strains. The results of this study showed that in the endolysin and endolysin + Ply6A3 treated mice, mortality rate and expression of procalcitonin, white blood cell, and interleukin-10 were significantly lower than the sepsis group. Indeed, phage PD-6A3 and endolysin Ply6A3 showed more activity than the cocktail of 14 phages. It should be noted that of all the phages used in this study, PD6A3 with a good host range (32.4\% (179 out of 552)) among clinical MDR A. baumannii isolates, showed the best performance compared to the other phages and intraperitoneal injection of this phage imposed no side effects on mice. ${ }^{80}$ Shivaswamy et al used phage to treat wound infection caused by MDR A. baumannii in uncontrolled diabetic rats. They reported that a significant decrease in infection and duration of epithelization, and early wound contraction was observed in rats treated with a local spray of $400 \mathrm{~mL}$ of $3 \times 10^{9}$ plaque-forming unit $(\mathrm{PFU}) / \mathrm{mL}$ Acinetobacter phage compared to untreated or treated with colistin groups. On the other hand, in this study, no side effects were reported in rats after phage administration; also, the phage control group appeared in good health. ${ }^{81}$ Finally, another study reported that administration of $5 \times 10^{7} \mathrm{pfu} / \mathrm{mL}$ of phage vB-GEC_Ab-M-G7, dsDNA myovirus with a $90 \mathrm{~kb}$ genome size, can reduce the number of bacteria and improve the wound infection caused by MDR A. baumannii in rats. Noteworthy, no side effects were observed in rats after the vB-GEC_Ab-M-G7 application, this indicates that the phages were non-toxic, resistant to chloroform, stable in different thermal and $\mathrm{pH}$ ranges and had a quite wide host range $(68 \%$ on 200 clinical strains). ${ }^{82}$ 
Therefore, as noted in the above studies, phages can be used to control wound infections caused by MDR A. baumannii strains and because of their ability to inhibit the septicemia caused by this bacterium, they can decrease the mortality rate of bloodstream infections in burn units. Interestingly, these phages are usually separated from hospital wastewater, so they have an excellent resistance to environmental changes and chemicals, which increases their chance to be used in bedside.

\section{Staphylococcus aureus}

Wounds are one of the most susceptible sites for infection by various pathogens, especially $S$. aureus, in developing countries. $^{83,84}$ In recent years, antibiotic resistance in $S$. aureus has led to the increased rates of mortality, morbidity, costs and period of hospitalization. ${ }^{85,86}$ It is challenging to manage antibiotic-resistant $S$. aureus in hospitals, especially in burn units. Therefore, researchers are developing novel methods such as phage therapy. ${ }^{87,88}$

In a study, Seth et al developed a skin lesion in the New Zealand rabbit ear and inoculated $S$. aureus to form a biofilm in the wound site. The wounds were treated locally with debridement, $S$. aureus-specific bacteriophage, and a combination of debridement and $S$. aureus-specific bacteriophage. Although phage therapy and debridement alone reduced the rate of $S$. aureus biofilm infection in rabbit wounds, this decrease was not significant. But the results showed that combination of phage therapy and debridement significantly reduced the rate of wound infection. ${ }^{89}$ In 2016, a study investigated the combination therapy of endolysin MR-10 and minocycline in the treatment of MRSA-induced systemic and local burn infections in mice. The results showed that in combination therapy using endolysin MR-10 phage and minocycline, all of the mice in the group with systemic MRSA infection survived. The load of bacteria decreased significantly in the group treated with combination therapy. Compared to the control group that received no treatment, a significant decrease in the amounts of 4.82, 1.51, 1.81, 1.2 logs were observed in skin, liver, blood, and spleen, respectively. Histopathological analysis did not show any signs of bacterial inflammation and infection in the combination treatment group. Finally, combination therapy for topical wound infection results in an early remission of the infection, furthermore, phage therapy results in controlling septicemia thereby reducing the mortality of wound infections by reducing the bacterial load in the blood. ${ }^{90}$ In 2018, a study investigated the use of bacteriophages to heal wounds in a diabetic mouse MRSA infection. In this study, two specific lytic phages of
S. aureus (MR-5 and MR-10) were used alone, as a cocktail, or in liposomal form. In mice treated with a phage cocktail, a significant decrease in a load of MRSA, faster tissue healing, and wound closure than the monophage treated group was observed. Also, to increase phage viability and availability, the phage cocktail was encapsulated in the liposomes, and it was shown that a phage cocktail along with liposomes could increase phage survival in the wound site. ${ }^{91}$ In another study, lytic bacteriophage MR-10 was tested in combination with linezolid as a treatment for MRSA infection in a population of diabetic BALB/c mice. Administration of a single dose of phage MR-10 showed similar efficacy with the linezolid antibiotic in treating the wound infection pathway of diabetic mice. However, combination of phage and linezolid were highly effective throughout the infection process including lesion score, bacterial load, foot histological analysis, and food myeloperoxidase activity, also, the tissue healing process was faster. ${ }^{92}$ Cheng et al designed an ointment consisting of the phage Lysin LysGH15 and Apigenin (Api) (a naturally occurring plant flavonoid) to combat MRSA. The results showed that phage lysGH15 has highly efficient lytic activity against MRSA and methicillin-susceptible strains of S. aureus (MSSA). Furthermore, Api showed a noticeable anti-inflammatory function and reduced hemolysis effects induced by $S$. aureus. Adding LysGH15 and Api to Aquaphor form, LysGH15-api-Aquaphor ointment (LAA), showed antibacterial activity against $S$. aureus and inhibited hemolysis. The effect of LAA on MRSA-infected wound showed that not only the bacterial colony count reduced to about $10^{2} \mathrm{CFU} / \mathrm{mg}$ in $18 \mathrm{~h}$ after treatment, but also the ointment decreased anti-inflammatory cytokines and wound healing was accelerated in the mouse model. Thus, this compound inhibits wound infection caused by MRSA; also, it accelerates the process of wound healing by reducing inflammation. ${ }^{93}$

Fish et al in a large clinical study evaluated the use of bacteriophage Sb-1 for the treatment of $S$. aureus-foot ulcers in six patients. All patients had a poor response to routine antibiotic therapy, so all of them received a course of bacteriophage treatment with successful healing of the wound in the toes. In the course of treatment with phage, the progression of wound healing was smooth and continuous, and no tissue breakage, adverse effects, and recurrence of infection were observed. ${ }^{94}$ In another study in six patients, bacteriophage Sb-1 was investigated on wounds of diabetic patients containing culture-proven $S$. aureus. The phage solution ( 0.1 to $0.5 \mathrm{cc}$, depending on the size and area of the wound) was applied topically to the wounds once a week after standard wound care. Findings 
showed that due to poor vascularity, antibiotic treatment was not sufficient to eliminate the infection, but an average of 7 weeks topical use of a staphylococcal phages could successfully heal infected toe wound. ${ }^{95}$

The results of various studies provide information about phage as a topical antimicrobial agent that is effective against $S$. aureus. Specifically, these studies provide evidence that topical application of phage alone or in combination with antibiotics has the potential to be an alternative strategy for antibiotic-resistant $S$. aureus infections. Noteworthy, various studies have reported significantly low side effects for phages, which make them more likely to be used in patients with an underlying disease such as diabetes.

\section{Klebsiella pneumoniae}

$K$. pneumoniae is an important nosocomial pathogen that is well known due to its widespread antibiotic resistance and high pathogenicity. ${ }^{96,97}$ The ability of resistance to common antibiotics has made the management of $K$. pneumoniae a major challenge, especially in burn patients. ${ }^{98,99}$ Among gram-negative bacteria that cause burn infections, K. pneumoniae is responsible for $15.2 \%$ of the infections. ${ }^{100}$ According to the vast spread of antibiotic resistance and the lack of new antibiotics, researchers introduced phage as a novel treatment for K. pneumoniae wound infection. ${ }^{101,102}$

In a study of burn infection caused by $K$. pneumoniae in mice, the therapeutic properties of the liposomal formulation loaded with phage cocktail (KØ1, KØ2, KØ3, КØ4 and KØ5) were evaluated for wound healing. As a result, the mice treated with liposomal trapped phage cocktail showed a large decrease in bacterial load in the blood $\left(10^{8} \mathrm{PFU} / \mathrm{mL}\right)$ and damaged organs $\left(10^{5} \mathrm{PFU} / \mathrm{mL}\right)$. Therefore, using this compound can reduce septicemia caused by wound infection and reduce mortality in patients. Also, It has been shown that liposomes increase the shelf life of the phage in vivo and enhance its efficacy. ${ }^{103}$ Chadha et al tested the therapeutic effect of monophage (Kpn1, Kpn2, Kpn3, Kpn4, and Kpn5) in comparison to the cocktail of these phages in the treatment of wound infection of $K$. pneumoniae in BALB/c mice. The monophage $(50 \mathrm{~mL}$ of $10^{8} \mathrm{PFU} / \mathrm{mL}$ ) found to be capable of treating $\mathrm{K}$. pneumoniae infection, but using $50 \mathrm{~mL}$ of $10^{8} \mathrm{PFU} / \mathrm{mL}$ phage cocktail was much effective in inhibiting the entire infection including wound contraction, bacterial load, histopathological analysis, skin myeloperoxidase activity, and collagen formation. ${ }^{104}$ In another study, researchers examined the effect of five phages (Kpn5, Kpn12, Kpn13, Kpn17, and Kpn22) on the survival of $K$. pneumoniae, causing wound infection, regeneration of skin cells, and reducing bacterial counts in different organs of mice. The researchers found that a single dose of phage suspensions (0.25 mL of $108 \mathrm{PFU} / \mathrm{mL}$ ), intraperitoneally, mainly reduced mortality of $K$. pneumoniae wound infection. Also, the histopathological results of phage treated mice showed that burn infection was completely cured. Finally, they reported that Kpn5 phage was the most effective phage, and a cocktail of all phages was effective, equally. ${ }^{24}$ Malik et al investigated the efficacy of bacteriophage KØ1 therapy via the subcutaneous or intraperitoneal route of lethal K. pneumoniae infection in the third-degree burn wound model infection in mice. A significant decrease in bacterial load in peritoneal lavage, lung tissue, and blood was observed after $10^{8} \mathrm{PFU} / \mathrm{mL}$ of bacteriophage treatment. ${ }^{102}$ In 2011, Kumari et al assessed the inhibitory and antimicrobial effects of phage Kpn5, silver nitrate, and gentamicin on $K$. pneumoniae in mice burn wounds. For this test, silver nitrate, gentamicin and phage Kpn5 (mixed in hydrogel) was applied daily to the wound site after infection. Interestingly, the results of this study showed that a single dose of $0.5 \mathrm{~mL} \mathrm{Kpn} 5$ phage $\left(10^{10} \mathrm{PFU} / \mathrm{mL}\right)$ and daily administration of silver nitrate and gentamicin significantly reduced mortality in mice. However, the level of protection for silver nitrate and gentamicin was lower than the phage treatment ${ }^{105}$. In another study, an experimental model of burn wound infection was developed in mice using K. pneumoniae B5055 to evaluate the therapeutic effect of Kpn5 phage in vivo. This phage $\left(10^{8} \mathrm{PFU} / \mathrm{mL}\right)$ was administered immediately after bacterial challenge, and the results showed that Kpn5 was effective in the treatment of $K$. pneumoniae -induced wound infection in mice. The remarkable result of this study indicated that the levels of anti-inflammatory cytokines (IL-10) and inflammatory cytokines (IL-1 $\beta$ and TNF- $\alpha$ ) in the serum and lungs of phage-treated mice was significantly lower than the untreated mice. $^{106}$

Patel et al used bacteriophages to treat patients with chronic non-healing wounds in vivo. The non-healing wounds were contaminated by various bacteria, such as $K$. pneumoniae, as one of the generative agents of the infection. Monophage $\left(10^{9} \mathrm{PFU} / \mathrm{mL}\right)$ was used for wound infections and $10^{9} \mathrm{PFU} / \mathrm{mL}$ cocktails were applied on the infected wound site surface each day. Patients were followed up for three months after the initiation of treatment. The cure rate of the treatment was $81.2 \%$. Particularly, $90.5 \%$ of the treated patients (19 out of 21 cases) were non-diabetic, and $74.1 \%$ of them (20 out of 27 cases) were diabetic. Interestingly, there was a delay in the treatment of wounds infected with $K$. pneumoniae compared to the other bacterial infections. Finally, the topical phage therapy was a promising method 
for the treatment of non-healing wounds in different patients because after phage treatment, hemoglobin levels and lymphocyte percentages were significantly increased. ${ }^{107}$

It can be concluded that bacteriophages can treat $K$. pneumoniae wound infection in a mice model. Furthermore, using a cocktail of phages instead of monophage can be more effective in reducing the number of bacteria and inhibiting wound infections compared to the MDR $K$. pneumoniae drugs. Therefore, the use of phage therapy can be a promising method for the treatment of $K$. pneumoniae infection, especially in the burned sites and in the antibiotic resistance conditions.

\section{So Why Is Phage Therapy Less Used?}

As discussed in the preceding sections, different phages can have good inhibitory effects on MDR bacteria, causing wound infections and accelerate the wound healing process. However, the use of phages is not currently widespread because of some issues. In this section, we present a complete list of challenges that hinder the use of phage therapy. Future studies with a greater focus on resolving these problems may widespread the use of phages in clinical practice.

\section{Bacteria Can Become Resistant to Phages}

Several mechanisms are involved in this issue, such as receptor alteration, restriction-modification and abortive infection systems, BREX and quorum sensing defense and adaptive immunity system by CRISPER sequences. Although the mechanism for phage resistance is different from antibiotic resistance, in the end, both have the same results; the therapeutic agents become ineffective. On the other hand, it is possible to use phage cocktails, but there are some concerns about bacteria resistance to phage cocktails. ${ }^{21,108,109}$

\section{The Possibility of Horizontal Gene Transfer by Phage}

Phages can carry virulent genes or antimicrobial resistance genes. So, phages are capable of transducing novel genes to the other pathogens, for example, transduction of pathogenicity islands in $S$. aureus. Therefore, using DNA sequencing methods ensures that therapeutic phages are not carrying virulent genes or pathogenicity islands. ${ }^{109-112}$

The Possibility of Picking Up Genetic Elements via Horizontal Gene Transfer by Phage

A few phages can take virulent bacterial genes by horizontal gene transfer and produce bacterial toxins, like enterotoxins.
For preventing this problem, only host DNA free phages, confirmed by polymerase chain reaction (PCR) method, should be used for therapeutic purposes. ${ }^{113,114}$

\section{Narrow Host Range}

Generally, it is accepted that most of the phages have a narrow host range, which is limited to the natural host for a single phage. But by using a mixture of phages as a cocktail, treatments become more efficient and can act against a single or multiple strains. ${ }^{113,115}$

\section{Identification of Infectious Agents to Select the Most Effective Phage and the Availability of Suitable Phage}

It is essential to determine which bacteria species is causing infection, and it is necessary to evaluate in vitro activity to select the best phage for therapeutic purposes within the phage libraries. This process is time-consuming in most laboratories, and the time spent to prepare phages may limit its use in treating patients. Furthermore, it is crucial to have several well-characterized phages for different kinds of pathogens. ${ }^{110,116}$

\section{Inability to Infect Intracellular Pathogens}

Surviving inside eukaryotic cells is an advantage for some pathogens. When bacterial pathogens enter host cells, phages lose the ability to reach their receptors; therefore, they will not be able to infect these pathogens and inhibit infections caused by intracellular bacteria. ${ }^{113,117}$ On the other hand, in recent years some studies have mentioned the efficiency of phage therapy against some intercellular pathogens like Salmonella infections in the poultry. ${ }^{118,119}$ So, phages may have the ability to interact with eukaryotic cells, penetrate theme and kill intracellular bacteria, but this depend on the strain and administration of the phage. ${ }^{119,120}$ Noteworthy, further studies are required to clarify the interaction between phage and intracellular bacteria.

\section{Detection as Invader Antigens}

Phages are not pathogens for eukaryotic cells, but sometimes the immune system detects them as foreign invaders and produces antibodies against them. Furthermore, administering a high dosage of phage must be avoided due to the risk of severe immune reaction. ${ }^{113,117}$ Besides, the immune system response can result in removing the phages, which decreases its concentration to an ineffective dose. ${ }^{21,116}$ 


\section{High Phage Concentrations in Ecosystems}

Phages are present in all environments and are stable in a wide range of temperatures. Unlike antibiotics, they are more resistant in the environment, and using phage therapy in high dosages may have adverse effects on the ecosystems and impose further imbalances on the environment. Therefore, preventing the unwilling impact of phages on the environment could be challenging. ${ }^{113,121}$

\section{Releasing Endotoxins}

As lytic phage attack Gram-negative bacteria, endotoxin release as one of the cellular components, this is one of the major issues related to phage therapy. Furthermore, endotoxin could activate immune responses, causing fever, septic shock, and even death. The solution to this problem is to use lysis-deficient phages. Endolysins are enzymes produced by the phages that degrade peptidoglycan and leading to immune system response. Developing genetically engineered endolysin-free phages made the prevention of severe immune responses possible and, as a result, kills pathogens, more efficiently. ${ }^{113,116,122,123}$

\section{Divers' Stability in Different Conditions}

Phages survive under hostile conditions such as low or high temperature and $\mathrm{pH}$, but this feature is very diverse and can differ among various phage families. Also, surviving is a multifactor parameter, and changing one factor can affect the other factors. Therefore, the properties of phages must be identified well to use them properly to achieve excellent results. ${ }^{124,125}$

\section{Restriction of Temperate Phages to Use}

Temperate phages eventually cause the death of its bacterial host but also, they can be integrated into the bacterial genome. Furthermore, temperate phages may not show a bactericidal effect instantly, and they would not be efficient in acute infections. Also, due to temperate phages integration into the bacterial host genome causing the occurrence of superinfection immunity, a condition that caused sensitive bacteria, insensitive to other phages. ${ }^{126-128}$ Also, one main reason for the restriction of temperate phage in phage therapy is the possibility of horizontal gene transfer via transduction. Mainly, specialized transduction that is usually mediated through temperate phage. Additionally, temperate phages with virulent genes can lead to lysogenic conversion.
A phenomenon that turns non-virulent bacteria into the virulent ones, like Escherichia coli O157: H7 that gain to prophages encoding Shiga toxin or СТХФ encoding the cholera toxin for Vibrio cholera. ${ }^{126,127,129-131}$ Therefore, only lytic phages should be used for treatment, and temperate phages are not useful. ${ }^{128}$

\section{Lack of Clear Guidelines}

There is a long history of phage therapy in Eastern Europe and the former Soviet Union. However, still, there are no authorized instructions for using phages on humans in the western countries, and current methods are only approved in some countries like Russia and Georgia. ${ }^{132,133}$ Noteworthy, the clinical trials phase I was approved by the Food and Drug Administration (FDA), and no safety concerns were found. ${ }^{132,134}$ So, a comprehensive guideline is needed to be available to all researchers to reduce phage therapy restriction.

\section{Phage Therapy Is Not Covered by Public Health Insurance}

Currently, phage therapy is not covered by public health insurance in many countries around the world (except Switzerland and Poland); this can add additional cost for patients. $^{21,135,136}$

\section{Phage Is Not Accepted as Pharmaceutical Drugs}

Phage is not recognized as a pharmaceutical agent, and European pharmacological regulations definitions and standards are not fully adjusted to phage preparations. Therefore, a Belgian organization, developed by a research group called P.H.A.G.E. (Phages for Human Application Group Europe) and some members of the Pasteur Institute in Paris, were formed to create a structure for the use of phage. ${ }^{116}$

\section{Inconsistency in the in vitro and in vivo Findings}

It is challenging to extrapolate the in vitro results with the in vivo findings. Applying the in vitro result in the clinical settings is sometimes too risky, and it should be used with caution. Therefore designing a model to evaluate the implications of phage therapy at the bedside is complicated. $^{21,137}$ 


\section{Conclusion and Future Direction}

Bacteriophages have an excellent ability to inhibit MDR bacterial pathogens and wound infections and accelerate wound healing. Also, studies have shown that phages can prevent septicemia caused by pathogens that colonize wounds, thereby preventing multiple organ failure and death. Furthermore, phages have good stability in different environmental conditions. Also, based on the studies, they have negligible side effects, which may increase their potential to be used for patients with underlying diseases or unstable physiological conditions, because they are more tolerable for patients than the toxic antibiotics. On the other hand, phages have different host range in various studies, which limits their use because wound-infecting pathogens are usually nosocomial bacteria that may have different origins, and the isolated phage may not be able to infect some of them. Also, isolation of specific phages may be timeconsuming and unnecessary for the patient. Furthermore, phages have low stability in long-term storage, but it is possible to use them in different ways, such as liposomal capsules and lyophilization. Therefore, using phages along with antibiotics, natural substances that have antimicrobial properties, or biological bands that increase wound healing can increase the chances of successful treatment. It is noteworthy that, using phage cocktails and providing phage banks can also increase their chances of success, as this is less time-consuming to isolate them, and it covers a wider hosting range. However, determining the use of phages to do the least harm to the human, methods to boost its effect on bacterial pathogens, the best time for the treatment, and the route or the dosage of the administration needs further studies. Nonetheless, phages may be introduced as a potential alternative for antibiotics, anytime soon.

\section{Acknowledgment}

We greatly appreciate the input from Melika Khanzadeh Tehrani (from Department of Pathobiology, School of Public Health, Tehran University of Medical Sciences, Tehran, Iran) for her collaboration with us in figures design.

\section{Disclosure}

The authors report no conflicts of interest in this work.

\section{References}

1. Simões D, Miguel SP, Ribeiro MP, Coutinho P, Mendonça AG, Correia IJ. Recent advances on antimicrobial wound dressing: a review. Eur j Pharm Biopharm. 2018;127:130-141. doi:10.1016/ j.ejpb.2018.02.022

2. Chua AWC, Khoo YC, Tan BK, Tan KC, Foo CL, Chong SJ. Skin tissue engineering advances in severe burns: review and therapeutic applications. Burns Trauma. 2016;4(1):3. doi:10.1186/ s41038-016-0027-y

3. Fijan S, Frauwallner A, Langerholc T, et al. Efficacy of using probiotics with antagonistic activity against pathogens of wound infections: an integrative review of literature. Biomed Res Int. 2019;2019.

4. Bowler P, Duerden B, Armstrong DG. Wound microbiology and associated approaches to wound management. Clin Microbiol Rev. 2001;14(2):244-269. doi:10.1128/CMR.14.2.244-269.2001

5. Wu X-D, Liu -M-M, Liang X, Hu N, Huang W. Effects of perioperative supplementation with pro-/synbiotics on clinical outcomes in surgical patients: a meta-analysis with trial sequential analysis of randomized controlled trials. Clin Nutri. 2018;37 (2):505-515. doi:10.1016/j.clnu.2016.10.015

6. Burnham JP, Kirby JP, Kollef MH. Diagnosis and management of skin and soft tissue infections in the intensive care unit: a review. Intensive Care Med. 2016;42(12):1899-1911. doi:10.1007/ s00134-016-4576-0

7. Cardona AF, Wilson SE. Skin and soft-tissue infections: a critical review and the role of telavancin in their treatment. Clin Infect Dis. 2015;61(suppl_2):S69-S78. doi:10.1093/cid/civ528

8. Shariati A, Moradabadi A, Azimi T, Ghaznavi-Rad E. Wound healing properties and antimicrobial activity of platelet-derived biomaterials. Sci Rep. 2020;10(1):1-9. doi:10.1038/s41598-020-57559-w

9. Andonova M, Urumova V. Immune surveillance mechanisms of the skin against the stealth infection strategy of Pseudomonas aeruginosa. Comp Immunol Microbiol Infect Dis. 2013;36 (5):433-448. doi:10.1016/j.cimid.2013.03.003

10. Shariati A, Asadian E, Fallah F, et al. Evaluation of Nano-curcumin effects on expression levels of virulence genes and biofilm production of multidrug-resistant Pseudomonas aeruginosa isolated from burn wound infection in Tehran, Iran. Infect Drug Resist. 2019;12:2223. doi:10.2147/IDR.S213200

11. Murray PM, Finegold SM. Anaerobes in burn-wound infections. Rev Infect Dis. 1984;6(Supplement_1):S184-S186. doi:10.1093/ clinids/6.Supplement_1.S184

12. Glik J, Kawecki M, Gaździk T, Nowak M. The impact of the types of microorganisms isolated from blood and wounds on the results of treatment in burn patients with sepsis. Polish J Surg. 2012;84(1):6-16. doi:10.2478/v10035-012-0002-7

13. Bahramian A, Khoshnood S, Shariati A, Doustdar F, Chirani AS, Heidary M. Molecular characterization of the pilS2 gene and its association with the frequency of Pseudomonas aeruginosa plasmid pKLC102 and PAPI-1 pathogenicity island. Infect Drug Resist. 2019;12:221. doi:10.2147/IDR.S188527

14. Shafiq M, Huang J, Rahman SU, et al. High incidence of multidrug-resistant Escherichia coli coharboring mcr-1 and blaCTX-M-15 recovered from pigs. Infect Drug Resist. 2019;12:2135. doi:10.2147/IDR.S209473

15. Abat C, Fournier P-E, Jimeno M-T, Rolain J-M, Raoult D. Extremely and pandrug-resistant bacteria extra-deaths: myth or reality? Eur J Clin Microbiol Infect Dis. 2018;37(9):1687-1697. doi:10.1007/s10096-018-3300-0

16. Kwiatek M, Parasion S, Nakonieczna A. Therapeutic bacteriophages as a rescue treatment for drug-resistant infections-an in vivo studies overview. J Appl Microbiol. 2019. 
17. Kutter E, Kuhl S, Alavidze Z, Blasdel B. Phage therapy: bacteriophages as natural, self-limiting antibiotics. Textbook Nat Med. 2005;112:945-956.

18. Sevgi M, Toklu A, Vecchio D. R Hamblin M. Topical antimicrobials for burn infections-an update. Recent Pat Antiinfect Drug Discov. 2013;8(3):161-197. doi:10.2174/1574891X086661311 12143447

19. Cooper R, Kirketerp-Møller K. Non-antibiotic antimicrobial interventions and antimicrobial stewardship in wound care. $J$ Wound Care. 2018;27(6):355-377. doi:10.12968/jowc.2018.27.6.355

20. Tsiouris CG, Kelesi M, Vasilopoulos G, Kalemikerakis I, Papageorgiou EG. The efficacy of probiotics as pharmacological treatment of cutaneous wounds: meta-analysis of animal studies. Eur J Pharm Sci. 2017;104:230-239. doi:10.1016/j.ejps.2017.04.002

21. Moghadam MT, Amirmozafari N, Shariati A, et al. How phages overcome the challenges of drug resistant bacteria in clinical infections. Infect Drug Resist. 2020;13:45. doi:10.2147/IDR.S234353

22. Azimi T, Mosadegh M, Nasiri MJ, Sabour S, Karimaei S, Nasser A. Phage therapy as a renewed therapeutic approach to mycobacterial infections: a comprehensive review. Infect Drug Resist. 2019;12:2943. doi:10.2147/IDR.S218638

23. Matsuzaki S, Rashel M, Uchiyama J, et al. Bacteriophage therapy: a revitalized therapy against bacterial infectious diseases. $J$ Infect Chemother. 2005;11(5):211-219. doi:10.1007/s10156005-0408-9

24. Kumari S, Harjai K, Chhibber S. Efficacy of bacteriophage treatment in murine burn wound infection induced by Klebsiella pneumoniae. J Microbiol Biotechnol. 2009;19(6):622-628. doi:10.4014/jmb.0808.493

25. Falagas ME, Bliziotis IA, Kasiakou SK, Samonis G, Athanassopoulou P, Michalopoulos A. Outcome of infections due to pandrug-resistant (PDR) Gram-negative bacteria. $B M C$ Infect Dis. 2005;5(1):24. doi:10.1186/1471-2334-5-24

26. Kunkalekar R, Prabhu M, Naik M, Salker A. Silver-doped manganese dioxide and trioxide nanoparticles inhibit both gram positive and gram negative pathogenic bacteria. Colloids Surf B Biointerfaces. 2014;113:429-434. doi:10.1016/j.colsurfb.2013.09.036

27. Morehead MS, Scarbrough C. Emergence of global antibiotic resistance. Primary Care. 2018;45(3):467-484. doi:10.1016/j. pop. 2018.05.006

28. Coll F, Phelan J, Hill-Cawthorne GA, et al. Genome-wide analysis of multi-and extensively drug-resistant Mycobacterium tuberculosis. Nat Genet. 2018;50(2):307-316. doi:10.1038/ s41588-017-0029-0

29. Anderson DJ, Chen LF, Weber DJ, et al. Enhanced terminal room disinfection and acquisition and infection caused by multidrug-resistant organisms and Clostridium difficile (the Benefits of Enhanced Terminal Room Disinfection study): a cluster-randomised, multicentre, crossover study. The Lancet. 2017;389(10071):805-814. doi:10.1016/S0140-6736(16)31588-4

30. Azimi T, Shariati A, Fallah F, et al. Mycobacterium tuberculosis genotyping using MIRU-VNTR typing. J Mazandaran Univ Med Sci. 2017;27(149):40-48.

31. Peters L, Olson L, Khu DT, et al. Multiple antibiotic resistance as a risk factor for mortality and prolonged hospital stay: a cohort study among neonatal intensive care patients with hospital-acquired infections caused by gram-negative bacteria in Vietnam. PLoS One. 2019;14:5. doi:10.1371/journal.pone.0215666

32. Rashel M, Uchiyama J, Ujihara T, et al. Efficient elimination of multidrug-resistant Staphylococcus aureus by cloned lysin derived from bacteriophage $\phi M R 11$. J Infect Dis. 2007;196 (8):1237-1247. doi:10.1086/521305

33. Pallavali RR, Degati VL, Lomada D, Reddy MC, Durbaka VRP. Isolation and in vitro evaluation of bacteriophages against MDR-bacterial isolates from septic wound infections. PLoS One. 2017;12:7. doi:10.1371/journal.pone.0179245
34. Mapes AC, Trautner BW, Liao KS, Ramig RF. Development of expanded host range phage active on biofilms of multi-drug resistant Pseudomonas aeruginosa. Bacteriophage. 2016;6(1): e1096995. doi:10.1080/21597081.2015.1096995

35. Larché J, Pouillot F, Essoh C, et al. Rapid identification of international multidrug resistant Pseudomonas aeruginosa clones by multiple locus VNTR analysis (MLVA) and investigation of their susceptibility to lytic bacteriophages. Antimicrob Agents Chemother. 2012. doi:10.1128/AAC.01233-12

36. Shokri D, Soleimani-Delfan A, Fatemi SM. Assessment of phage cocktails with extended host range activity against antibiotic resistant strains of Pseudomonas aeruginosa. Comp Clin Path. 2017;26(2):417-422. doi:10.1007/s00580-0162394-y

37. Nir-Paz R, Gelman D, Khouri A, et al. Successful treatment of antibiotic-resistant, poly-microbial bone infection with bacteriophages and antibiotics combination. Clin Infect Dis. 2019;69 (11):2015-2018. doi:10.1093/cid/ciz222

38. Shariati A, Azimi T, Ardebili A, et al. Insertional inactivation of oprD in carbapenem-resistant Pseudomonas aeruginosa strains isolated from burn patients in Tehran, Iran. New Microbes New Infect. 2018;21:75-80. doi:10.1016/j.nmni.2017.10.013

39. Bertoye A, Gaillard L, Courtieu A. Adapted bacteriophages in the treatment of infections caused by antibiotic-resistant microorganisms. J Med Lyon. 1959;40(945):465.

40. Bertoye A, Courtieu A. Treatment of infections caused by pyocyanic bacilli with bacteriophages adapted by selection. $J$ Med Lyon. 1960;41:739-751.

41. McVay CS, Velásquez M, Fralick JA. Phage therapy of Pseudomonas aeruginosa infection in a mouse burn wound model. Antimicrob Agents Chemother. 2007;51(6):1934-1938. doi:10.1128/AAC.01028-06

42. Basu S, Agarwal M, Kumar Bhartiya S, Nath G, Kumar Shukla V. An in vivo wound model utilizing bacteriophage therapy of pseudomonas aeruginosa biofilms. Ostomy Wound Manage. 2015;61(8):16-23.

43. Oliveira A, Sousa JC, Silva AC, Melo LD, Sillankorva S. Chestnut honey and bacteriophage application to control Pseudomonas aeruginosa and Escherichia coli biofilms: evaluation in an ex vivo wound model. Front Microbiol. 2018;9:1725. doi:10.3389/fmicb.2018.01725

44. Sarhan WA, Azzazy HM. Apitherapeutics and phage-loaded nanofibers as wound dressings with enhanced wound healing and antibacterial activity. Nanomedicine. 2017;12(17):2055-2067. doi:10.2217/nnm-2017-0151

45. Raz A, Serrano A, Hernandez A, Euler CW, Fischetti VA. Isolation of phage lysins that effectively kill Pseudomonas aeruginosa in mouse models of lung and skin infection. Antimicrob Agents Chemother. 2019;63(7):e00024-00019. doi:10.1128/AAC.00024-19

46. Soothill J. Bacteriophage prevents destruction of skin grafts by Pseudomonas aeruginosa. Burns. 1994;20(3):209-211. doi:10.1016/0305-4179(94)90184-8

47. Holguín A, Rangel G, Clavijo V, et al. Phage ФPan70, a putative temperate phage, controls Pseudomonas aeruginosa in planktonic, biofilm and burn mouse model assays. Viruses. 2015;7 (8):4602-4623. doi:10.3390/v7082835

48. Vieira A, Silva Y, Cunha A, Gomes N, Ackermann H-W, Almeida A. Phage therapy to control multidrug-resistant Pseudomonas aeruginosa skin infections: in vitro and ex vivo experiments. Eur J Clin Microbiol Infect Dis. 2012;31(11):3241-3249. doi:10.1007/s10096012-1691-x

49. Jault $P$, Leclerc $T$, Jennes $S$, et al. Efficacy and tolerability of a cocktail of bacteriophages to treat burn wounds infected by Pseudomonas aeruginosa (PhagoBurn): a randomised, controlled, double-blind Phase 1/2 trial. Lancet Infect Dis. 2019;19(1):35-45. doi:10.1016/S1473-3099(18)30482-1 
50. Sivera Marza J, Soothill J, Boydell P, Collyns T. Multiplication of therapeutically administered bacteriophages in Pseudomonas aeruginosa infected patients. Burns. 2006;32(5):644-646. doi:10.1016/j.burns.2006.02.012

51. Chang RYK, Das T, Manos J, Kutter E, Morales S, Chan H-K. Bacteriophage PEV20 and ciprofloxacin combination treatment enhances removal of Pseudomonas aeruginosa biofilm isolated from cystic fibrosis and wound patients. AAPS J. 2019;21(3):49. doi:10.1208/s12248-019-0315-0

52. Taha OA, Connerton PL, Connerton IF, El-Shibiny A. Bacteriophage ZCKP1: a potential treatment for Klebsiella pneumoniae isolated from diabetic foot patients. Front Microbiol. 2018;9:2127. doi:10.3389/fmicb.2018.02127

53. Barros J, Melo LD, Poeta P, et al. Lytic bacteriophages against multidrug-resistant Staphylococcus aureus, Enterococcus faecalis and Escherichia coli isolates from orthopaedic implant-associated infections. Int $J$ Antimicrob Agents. 2019;54(3):329-337. doi:10.1016/j.ijantimicag.2019.06.007

54. Jansen M, Wahida A, Latz S, et al. Enhanced antibacterial effect of the novel T4-like bacteriophage KARL-1 in combination with antibiotics against multi-drug resistant Acinetobacter baumannii. Sci Rep. 2018;8(1):1-12. doi:10.1038/s41598-018-32344-y

55. Capparelli R, Parlato M, Borriello G, Salvatore P, Iannelli D. Experimental phage therapy against Staphylococcus aureus in mice. Antimicrob Agents Chemother. 2007;51(8):2765-2773. doi:10.1128/AAC.01513-06

56. Morris JL, Letson HL, Elliott L, et al. Evaluation of bacteriophage as an adjunct therapy for treatment of peri-prosthetic joint infection caused by Staphylococcus aureus. PLoS One. 2019;14:12. doi:10.1371/journal.pone.0226574

57. Lehman SM, Mearns G, Rankin D, et al. Design and preclinical development of a phage product for the treatment of antibiotic-resistant Staphylococcus aureus infections. Viruses. 2019;11(1):88. doi:10.3390/v11010088

58. Takemura-Uchiyama I, Uchiyama J, Osanai $\mathrm{M}$, et al. Experimental phage therapy against lethal lung-derived septicemia caused by Staphylococcus aureus in mice. Microbes Infect. 2014;16(6):512-517. doi:10.1016/j.micinf.2014.02.011

59. Ding B, Li Q, Guo M, et al. Prevention of dermal abscess formation caused by Staphylococcus aureus using phage JD007 in nude mice. Front Microbiol. 2018;9:1553. doi:10.3389/ fmicb.2018.01553

60. Watanabe R, Matsumoto T, Sano G, et al. Efficacy of bacteriophage therapy against gut-derived sepsis caused by Pseudomonas aeruginosa in mice. Antimicrob Agents Chemother. 2007;51 (2):446-452. doi:10.1128/AAC.00635-06

61. Fukuda K, Ishida W, Uchiyama J, et al. Pseudomonas aeruginosa keratitis in mice: effects of topical bacteriophage KPP12 administration. PLoS One. 2012;7:10. doi:10.1371/journal. pone. 0047742

62. Wright A, Hawkins C, Änggård E, Harper D. A controlled clinical trial of a therapeutic bacteriophage preparation in chronic otitis due to antibiotic-resistant Pseudomonas aeruginosa; a preliminary report of efficacy. Clinical Otolaryngology. 2009;34(4):349-357. doi:10.1111/j.1749-4486.2009.01973.x

63. Wang J, Hu B, Xu M, et al. Use of bacteriophage in the treatment of experimental animal bacteremia from imipenem-resistant Pseudomonas aeruginosa. Int J Mol Med. 2006;17(2):309-317.

64. Duplessis C, Biswas B, Hanisch B, et al. Refractory Pseudomonas Bacteremia in a 2-year-old sterilized by bacteriophage therapy. J Pediatric Infect Dis Soc. 2018;7(3):253-256. doi:10.1093/jpids/ pix056

65. Hua Y, Luo T, Yang Y, et al. Phage therapy as a promising new treatment for lung infection caused by carbapenem-resistant Acinetobacter baumannii in mice. Front Microbiol. 2018;8:2659. doi:10.3389/fmicb.2017.02659
66. Schooley RT, Biswas B, Gill JJ, et al. Development and use of personalized bacteriophage-based therapeutic cocktails to treat a patient with a disseminated resistant Acinetobacter baumannii infection. Antimicrob Agents Chemother. 2017;61(10):e0095400917. doi:10.1128/AAC.00954-17

67. Wang J-L, Kuo C-F, Yeh C-M, Chen J-R, Cheng M-F, Hung C-H. Efficacy of $\varphi \mathrm{km} 18 \mathrm{p}$ phage therapy in a murine model of extensively drug-resistant Acinetobacter baumannii infection. Infect Drug Resist. 2018;11:2301. doi:10.2147/IDR.S179701

68. Wang Y, Mi Z, Niu W, et al. Intranasal treatment with bacteriophage rescues mice from Acinetobacter baumannii-mediated pneumonia. Future Microbiol. 2016;11(5):631-641. doi:10.2217/fmb.16.11

69. Hung C-H, Kuo C-F, Wang C-H, Wu C-M, Tsao N. Experimental phage therapy in treating Klebsiella pneumoniae-mediated liver abscesses and bacteremia in mice. Antimicrob Agents Chemother. 2011;55(4):1358-1365. doi:10.1128/AAC.01123-10

70. Cao F, Wang X, Wang L, et al. Evaluation of the efficacy of a bacteriophage in the treatment of pneumonia induced by multidrug resistance Klebsiella pneumoniae in mice. Biomed Res Int. 2015;2015.

71. Chhibber S, Kaur S, Kumari S. Therapeutic potential of bacteriophage in treating Klebsiella pneumoniae B5055-mediated lobar pneumonia in mice. J Med Microbiol. 2008;57(12):1508-1513. doi:10.1099/jmm.0.2008/002873-0

72. Anand T, Virmani N, Kumar S, et al. Phage therapy for treatment of virulent Klebsiella pneumoniae infection in mouse model. J Global Antimicrob Resist. 2019.

73. Corbellino M, Kieffer N, Kutateladze M, et al. Eradication of a multidrug-resistant, carbapenemase-producing klebsiella pneumoniae isolate following oral and intra-rectal therapy with a custom made, lytic bacteriophage preparation. Clin Infect Dis. 2019.

74. Khan A, Xu M, Wang T, et al. Catechol cross-linked antimicrobial peptide hydrogels prevent multidrug-resistant Acinetobacter baumannii infection in burn wounds. Biosci Rep. 2019;39:6. doi:10.1042/BSR20190504

75. Gholami M, Haghshenas M, Moshiri M, et al. Frequency of $16 \mathrm{~S}$ rRNA methylase and aminoglycoside-modifying enzyme genes among clinical isolates of Acinetobacter baumannii in Iran. Iran J Pathol. 2017;12(4):329-338.

76. Amin M, Navidifar T, Shooshtari FS, et al. Association between biofilm formation, structure, and the expression levels of genes related to biofilm formation and biofilm-specific resistance of acinetobacter baumannii strains isolated from burn infection in Ahvaz, Iran. Infect Drug Resist. 2019;12:3867. doi:10.2147/IDR.S228981

77. Regeimbal JM, Jacobs AC, Corey BW, et al. Personalized therapeutic cocktail of wild environmental phages rescues mice from Acinetobacter baumannii wound infections. Antimicrob Agents Chemother. 2016;60(10):5806-5816. doi:10.1128/AAC.02877-15

78. Leshkasheli L, Kutateladze M, Balarjishvili N, et al. Efficacy of newly isolated and highly potent bacteriophages in a mouse model of XDRAB bacteremia. J Global Antimicrob Resist. 2019;19:255-261. doi:10.1016/j.jgar.2019.05.005

79. Yin S, Huang G, Zhang Y, et al. Phage Abp1 rescues human cells and mice from infection by pan-drug resistant Acinetobacter baumannii. Cell Physiol Biochem. 2017;44(6):2337-2345. doi:10.1159/000486117

80. Wu M, Hu K, Xie Y, et al. A novel phage PD-6A3, and its endolysin Ply6A3, with extended lytic activity against Acinetobacter baumannii. Front Microbiol. 2019;9:3302. doi:10.3389/fmicb.2018.03302

81. Shivaswamy VC, Kalasuramath SB, Sadanand CK, et al. Ability of bacteriophage in resolving wound infection caused by multidrug-resistant Acinetobacter baumannii in uncontrolled diabetic rats. Microbial Drug Resist. 2015;21(2):171-177. doi:10.1089/mdr.2014.0120 
82. Kusradze I, Karumidze N, Rigvava S, et al. Characterization and testing the efficiency of Acinetobacter baumannii phage vB-GEC_Ab-M-G7 as an antibacterial agent. Front Microbiol. 2016;7:1590. doi:10.3389/fmicb.2016.01590

83. Norbury W, Herndon DN, Tanksley J, Jeschke MG, Finnerty CC, Society SSCotSI. Infection in burns. Surg Infect (Larchmt). 2016;17(2):250-255. doi:10.1089/sur.2013.134

84. Shahsavan S, Emaneini M, Khoshgnab BN, et al. A high prevalence of mupirocin and macrolide resistance determinant among Staphylococcus aureus strains isolated from burnt patients. Burns. 2012;38(3):378-382. doi:10.1016/j.burns.2011.09.004

85. Khosravi AD, Hoveizavi H, Farshadzadeh Z. The prevalence of genes encoding leukocidins in Staphylococcus aureus strains resistant and sensitive to methicillin isolated from burn patients in Taleghani Hospital, Ahvaz, Iran. Burns. 2012;38(2):247-251. doi:10.1016/j.burns.2011.08.002

86. Hashemi A, Jaberi S, Shariati A, et al. Identification of inducible clindamycin resistance in staphylococcus aureus strains isolated from hospitalized patients in hospitals of Tehran City (Iran). Qom Univ Med Sci J. 2018;11(12):52-60.

87. Murray CK, Holmes RL, Ellis MW, et al. Twenty-five year epidemiology of invasive methicillin-resistant Staphylococcus aureus (MRSA) isolates recovered at a burn center. Burns. 2009;35(8):1112-1117. doi:10.1016/j.burns.2009.02.013

88. Peng C, Hanawa T, Azam AH, et al. Silviavirus phage $\phi M R 003$ displays a broad host range against methicillin-resistant Staphylococcus aureus of human origin. Appl Microbiol Biotechnol. 2019;103(18):7751-7765. doi:10.1007/s00253-01910039-2

89. Seth AK, Geringer MR, Nguyen KT, et al. Bacteriophage therapy for Staphylococcus aureus biofilm-infected wounds: a new approach to chronic wound care. Plast Reconstr Surg. 2013;131 (2):225-234. doi:10.1097/PRS.0b013e31827e47cd

90. Chopra S, Harjai K, Chhibber S. Potential of combination therapy of endolysin MR-10 and minocycline in treating MRSA induced systemic and localized burn wound infections in mice. Int $\mathrm{J} \mathrm{Med}$ Microbiol. 2016;306(8):707-716. doi:10.1016/j.ijmm.2016. 08.003

91. Chhibber S, Kaur J, Kaur S. Liposome entrapment of bacteriophages improves wound healing in a diabetic mouse MRSA infection. Front Microbiol. 2018;9:561. doi:10.3389/fmicb.20 18.00561

92. Chhibber S, Kaur T, Kaur S. Co-therapy using lytic bacteriophage and linezolid: effective treatment in eliminating methicillin resistant Staphylococcus aureus (MRSA) from diabetic foot infections. PLoS One. 2013;8:2. doi:10.1371/journal.pone. 0056022

93. Cheng M, Zhang L, Zhang H, et al. An ointment consisting of the phage lysin LysGH15 and apigenin for decolonization of methicillin-resistant Staphylococcus aureus from skin wounds. Viruses. 2018;10(5):244. doi:10.3390/v10050244

94. Fish R, Kutter E, Wheat G, Blasdel B, Kutateladze M, Kuhl S. Compassionate use of bacteriophage therapy for foot ulcer treatment as an effective step for moving toward clinical trials. Bacteriophage Ther Springer. 2018;159-170.

95. Fish R, Kutter E, Wheat G, Blasdel B, Kutateladze M, Kuhl S. Bacteriophage treatment of intransigent diabetic toe ulcers: a case series. J Wound Care. 2016;25(Sup7):S27-S33. doi:10.12968/ jowc.2016.25.Sup7.S27

96. Kiaei S, Moradi M, Nave HH, Hashemizadeh Z, TaatiMoghadam M, Kalantar-Neyestanaki D. Emergence of co-existence of bla NDM with rmtC and qnrB genes in clinical carbapenem-resistant Klebsiella pneumoniae isolates in burning center from southeast of Iran. Folia Microbiol (Praha). 2019;64 (1):55-62. doi:10.1007/s12223-018-0630-3
97. Moradi M, Norouzi A, Taatimoghadam M. Prevalence of bla-CTX -M, bla-SHV, and bla-TEM Genes and comparison of antibiotic resistance pattern in extended-spectrum $\beta$-lactamase producing and non-producing groups of Klebsiella pneumoniae Isolated from Clinical Samples in Kerman Hospitals. J Fasa Univ Med Sci. 2016;6(1):120-128.

98. Sánchez M, Herruzo R, Marbán A, et al. Risk factors for outbreaks of multidrug-resistant Klebsiella pneumoniae in critical burn patients. J Burn Care Res. 2012;33(3):386-392. doi:10.1097/BCR.0b013e318231df95

99. Bahramian A, Shariati A, Azimi T, et al. First report of New Delhi metallo- $\beta$-lactamase-6 (NDM-6) among Klebsiella pneumoniae ST147 strains isolated from dialysis patients in Iran. Infect Genet Evol. 2019;69:142-145. doi:10.1016/j.meegid.2019.01.030

100. Nasser S, Mabrouk A, Maher A. Colonization of burn wounds in Ain Shams University burn unit. Burns. 2003;29(3):229-233. doi:10.1016/S0305-4179(02)00285-1

101. Bogovazova G, Voroshilova N, Bondarenko V. The efficacy of Klebsiella pneumoniae bacteriophage in the therapy of experimental Klebsiella infection. Zh Mikrobiol Epidemiol Immunobiol. 1991;(4):5-8.

102. Malik R, Chhibber S. Protection with bacteriophage KØ1 against fatal Klebsiella pneumoniae-induced burn wound infection in mice. J Microbiol Immunol Infect. 2009;42(2):134-140.

103. Chadha P, Katare OP, Chhibber S. Liposome loaded phage cocktail: enhanced therapeutic potential in resolving Klebsiella pneumoniae mediated burn wound infections. Burns. 2017;43 (7):1532-1543. doi:10.1016/j.burns.2017.03.029

104. Chadha P, Katare OP, Chhibber S. In vivo efficacy of single phage versus phage cocktail in resolving burn wound infection in BALB/c mice. Microb Pathog. 2016;99:68-77. doi:10.1016/j. micpath.2016.08.001

105. Kumari S, Harjai K, Chhibber S. Bacteriophage versus antimicrobial agents for the treatment of murine burn wound infection caused by Klebsiella pneumoniae B5055. J Med Microbiol. 2011;60(2):205-210. doi:10.1099/jmm.0.018580-0

106. Kumari S, Harjai K, Chhibber S. Evidence to support the therapeutic potential of bacteriophage Kpn5 in burn wound infection caused by Klebsiella pneumoniae in BALB/c mice. $J$ Microbiol Biotechnol. 2010;20(5):935-941. doi:10.4014/jmb.0909.09010

107. Patel DR, Bhartiya SK, Kumar R, Shukla VK, Nath G. Use of customized bacteriophages in the treatment of chronic nonhealing wounds: a prospective study. Int $J$ Low Extrem Wounds. 2019; 1534734619881076.

108. Örmälä A-M, Jalasvuori M. Phage therapy: should bacterial resistance to phages be a concern, even in the long run? Bacteriophage. 2013;3(1):e24219. doi:10.4161/bact.24219

109. Krylov V, Shaburova O, Krylov S, Pleteneva E. A genetic approach to the development of new therapeutic phages to fight Pseudomonas aeruginosa in wound infections. Viruses. 2013;5 (1):15-53. doi:10.3390/v5010015

110. Kutateladze M, Adamia R. Bacteriophages as potential new therapeutics to replace or supplement antibiotics. Trends Biotechnol. 2010;28(12):591-595. doi:10.1016/j.tibtech.2010.08.001

111. Dearborn AD, Dokland T. Mobilization of pathogenicity islands by Staphylococcus aureus strain Newman bacteriophages. Bacteriophage. 2012;2(2):70-78. doi:10.4161/bact.20632

112. Chen J, Novick RP. Phage-mediated intergeneric transfer of toxin genes. Science. 2009;323(5910):139-141. doi:10.1126/science.1164783

113. Doss J, Culbertson K, Hahn D, Camacho J, Barekzi N. A review of phage therapy against bacterial pathogens of aquatic and terrestrial organisms. Viruses. 2017;9(3):50. doi:10.3390/v9030050

114. Mohammed-Ali MN, Jamalludeen NM. Isolation and characterization of bacteriophage against methicillin resistant Staphylococcus aureus. J Med Microb Diagn. 2015;5 (213):2161-0703.1000213. 
115. Ross A, Ward S, Hyman P. More is better: selecting for broad host range bacteriophages. Front Microbiol. 2016;7:1352. doi: $10.3389 /$ fmicb. 2016.01352

116. Wittebole X, De Roock S, Opal SM. A historical overview of bacteriophage therapy as an alternative to antibiotics for the treatment of bacterial pathogens. Virulence. 2014;5(1):226-235. doi:10.4161/viru.25991

117. Sulakvelidze A, Alavidze Z, Morris JG. Bacteriophage therapy. Antimicrob Agents Chemother. 2001;45(3):649-659. doi:10.1128/ AAC.45.3.649-659.2001

118. Wernicki A, Nowaczek A, Urban-Chmiel R. Bacteriophage therapy to combat bacterial infections in poultry. Virol J. 2017;14 (1):179. doi:10.1186/s12985-017-0849-7

119. Żaczek M, Górski A, Skaradzińska A, Łusiak-Szelachowska M, Weber-Dąbrowska B. Phage penetration of eukaryotic cells: practical implications. Future Virol. 2019.

120. Jończyk-Matysiak E, Weber-Dąbrowska B, Owczarek B, et al. Phage-phagocyte interactions and their implications for phage application as therapeutics. Viruses. 2017;9(6):150. doi:10.3390/ v9060150

121. Meaden S, Koskella B. Exploring the risks of phage application in the environment. Front Microbiol. 2013;4:358. doi:10.3389/ fmicb.2013.00358

122. Nobrega FL, Costa AR, Kluskens LD, Azeredo J. Revisiting phage therapy: new applications for old resources. Trends Microbiol. 2015;23(4):185-191. doi:10.1016/j.tim.2015.01.006

123. Paul VD, Sundarrajan S, Rajagopalan SS, et al. Lysis-deficient phages as novel therapeutic agents for controlling bacterial infection. BMC Microbiol. 2011;11(1):195. doi:10.1186/14712180-11-195

124. Ackermann H-W, Tremblay D, Moineau S. Long-term bacteriophage preservation. WFCC Newsletter. 2004;38(1):35-40.

125. Jończyk E, Kłak M, Międzybrodzki R, Górski A. The influence of external factors on bacteriophages. Folia Microbiol (Praha). 2011;56(3):191-200. doi:10.1007/s12223-011-0039-8

126. Harrison E, Brockhurst MA. Ecological and evolutionary benefits of temperate phage: what does or doesn't kill you makes you stronger. BioEssays. 2017;39(12):1700112. doi:10.1002/bies.201700112
127. Monteiro R, Pires DP, Costa AR, Azeredo J. Phage therapy: going temperate? Trends Microbiol. 2019;27(4):368-378. doi:10.1016/j. tim.2018.10.008

128. Gorski A, Miedzybrodzki R, Borysowski J, et al. Bacteriophage therapy for the treatment of infections. Curr Opinion Invest Drugs. 2009;10(8):766-774.

129. Davies EV, Winstanley C, Fothergill JL, James CE. The role of temperate bacteriophages in bacterial infection. FEMS Microbiol Lett. 2016;363:5. doi:10.1093/femsle/fnw015

130. Shaikh N, Tarr PI. Escherichia coli O157: H7 Shiga toxin-encoding bacteriophages: integrations, excisions, truncations, and evolutionary implications. $J$ Bacteriol. 2003;185 (12):3596-3605. doi:10.1128/JB.185.12.3596-3605.2003

131. Waldor MK, Mekalanos JJ. Lysogenic conversion by a filamentous phage encoding cholera toxin. Science. 1996;272 (5270):1910-1914. doi:10.1126/science.272.5270.1910

132. Pirnay J-P, De Vos D, Verbeken G, et al. The phage therapy paradigm: pret-a-porter or sur-mesure? Pharm Res. 2011;28 (4):934-937. doi:10.1007/s11095-010-0313-5

133. Chanishvili N, Sharp R. Eliava Institute of bacteriophage, microbiology and virology, Tbilisi, Georgia. In: A Literature Review of the Practical Application of Bacteriophage Research Tbilisi. Eliava Foundation; 2009.

134. Kutter E, De Vos D, Gvasalia G, et al. Phage therapy in clinical practice: treatment of human infections. Curr Pharm Biotechnol. 2010;11(1):69-86. doi:10.2174/138920110790725401

135. Międzybrodzki R, Borysowski J, Weber-Dąbrowska B. et al., Clinical aspects of phage therapy. In: Advances in Virus Research. Vol. 83. Elsevier; 2012:73-121.

136. Stafford N. Switzerland Is to Fund Complementary Therapies for Six Years While Effectiveness Is Evaluated. British Medical Journal Publishing Group; 2011.

137. Weld RJ, Butts C, Heinemann JA. Models of phage growth and their applicability to phage therapy. J Theor Biol. 2004;227 (1):1-11. doi:10.1016/S0022-5193(03)00262-5

\section{Publish your work in this journal}

Drug Design, Development and Therapy is an international, peerreviewed open-access journal that spans the spectrum of drug design and development through to clinical applications. Clinical outcomes, patient safety, and programs for the development and effective, safe, and sustained use of medicines are a feature of the journal, which has also been accepted for indexing on PubMed Central. The manuscript management system is completely online and includes a very quick and fair peer-review system, which is all easy to use. Visit http://www. dovepress.com/testimonials.php to read real quotes from published authors. 